\title{
Daoism, Flourishing, and Gene Editing
}

\author{
Richard Kim \\ Loyola University Chicago, rkim7@luc.edu
}

Follow this and additional works at: https://ecommons.luc.edu/philosophy_facpubs

Part of the Philosophy Commons

\section{Recommended Citation}

Kim, Richard. "Daoism, Flourishing, and Gene Editing", in Human Flourishing in an Age of Gene Editing edited by Erik Parens and Josephine Johnston, Oxford University Press, 2019.

This Book Chapter is brought to you for free and open access by the Faculty Publications and Other Works by Department at Loyola eCommons. It has been accepted for inclusion in Philosophy: Faculty Publications and Other Works by an authorized administrator of Loyola eCommons. For more information, please contact ecommons@luc.edu.

\section{(c) (1) $(9)$}

This work is licensed under a Creative Commons Attribution-Noncommercial-No Derivative Works 3.0 License. (c) Oxford University Press, 2019. 


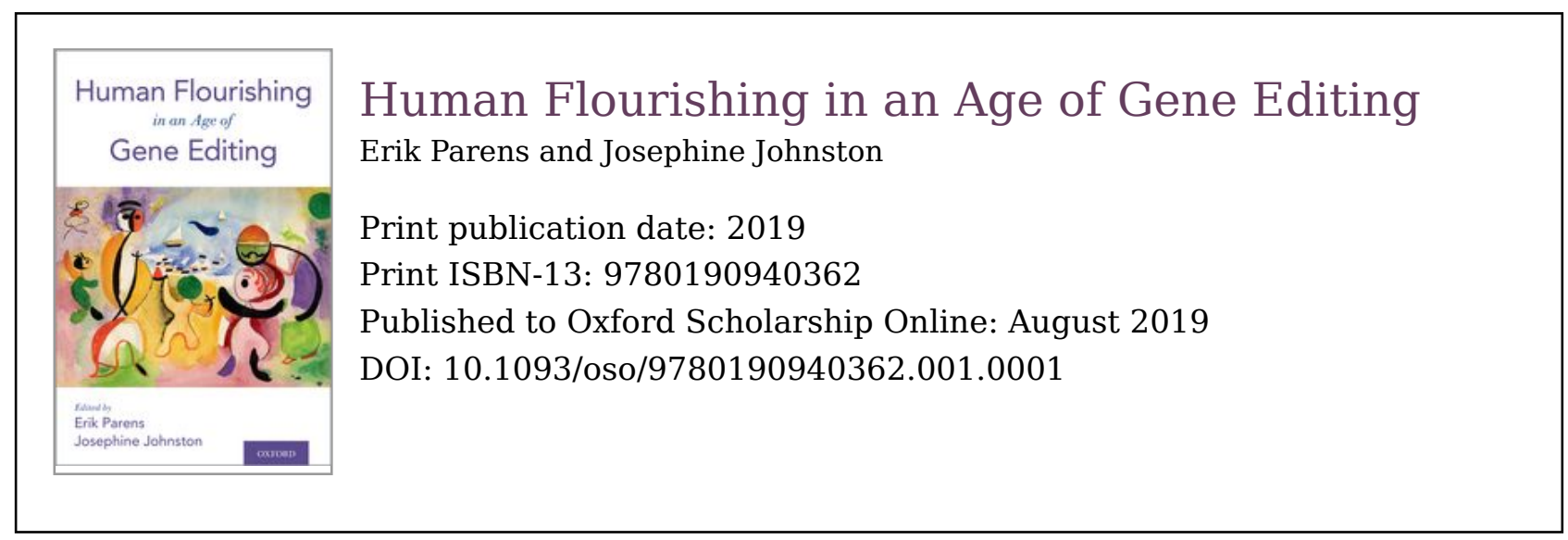

\title{
Daoism, Flourishing, and Gene Editing
}

Richard Kim

DOI:10.1093/oso/9780190940362.003.0006

\begin{abstract}
Keywords
Given the potentially powerful effects of gene editing for human lives, it seems reasonable to reflect on the issue from a variety of scientific, moral, cultural, and religious perspectives to help us deploy this technology with a clear eye to all its possible implications. Given the global impact genetic modification will likely have, an inquiry seriously engaging with the values and ideals of non-Western cultures and societies will be helpful to achieve the sort of balanced understanding that will enable a proper evaluation. This chapter examines the account of well-being found in the Daoist classic, the Zhuangzi, and highlights some insights that can be fruitfully explored in the context of the ethics of gene editing. The thesis is that, from the perspective of Zhuangzi's conception of human flourishing, there are reasons for rejecting the use of genetic modification technology.
\end{abstract}

Keywords: Daoism, Zhuangzi, well-being, flourishing, gene editing, Chinese philosophy

Given the potentially powerful effects of gene editing for human lives, it seems reasonable to reflect on the issue from a variety of scientific, moral, cultural, and religious perspectives to help us deploy this technology with a clear eye to all its possible implications. Given the global impact genetic modification will likely have, an inquiry seriously engaging with the values and ideals of non-Western cultures and societies will be helpful to achieve the sort of balanced understanding that will enable a proper evaluation. 
The focus of this chapter is on one of the oldest, richest, and most influential moral traditions that arose in early China: Daoism. One key feature of Daoism, shared by other great philosophical traditions of early China such as Confucianism and Mohism, is its practical orientation. Although the Daoist texts represent a number of intriguing philosophical positions, they ultimately aim at helping readers achieve human fulfillment. Like the great eudaemonist traditions of the West such as Stoicism or Aristotelianism (see Daniel Haybron's Chapter 2, this volume), at the heart of the Daoist philosophical tradition is the attainment of flourishing or well-being. (I use these terms interchangeably.) This chapter examines the account of well-being found in the Daoist classic, the Zhuangzi, and highlights some insights that can be fruitfully explored in the context of the ethics of gene editing. My thesis is that from the perspective of Zhuangzi's conception of human flourishing, we have reasons to think we should reject the use of genetic modification technology. In this chapter, I do not attempt to settle whether, all things considered, those reasons are strong enough to support the rejection of any one form or use, much less all, of gene editing.

Gene editing technologies can be aimed at a variety of purposes, including what bioethicists refer to as "therapy" and "enhancement." Giubilini and Sanyal defined enhancement as "biomedical interventions to improve human capacities, performances, dispositions, and well-being beyond the traditional scope of therapeutic medicine."2 Therapy, on the other hand, is understood as the restoration of human capacities to their normal or characteristic function. ${ }^{3}$ This chapter explores reasons to think we should reject the use of human genetic modification technologies generally, when put to both enhancement and therapeutic ends. Because the therapeutic use of gene editing, at least for somatic (p.73) engineering, is widely accepted, Zhuangzi's views will strike most readers as extreme (and perhaps unhelpful) in deepening our ethical understanding of the topic of gene editing. ${ }^{4}$ But even if a wholesale endorsement of Zhuangzi's views is unlikely, there are elements of his thinking that merit careful consideration and can draw attention to possible negative consequences of deploying human gene editing technologies.

Zhuangzi's primary goal was not to build a coherent ethical system or uncover a set of fundamental moral principles. In line with many of the Hellenistic philosophers like the Stoics and Epicureans, Zhuangzi sought to reshape the reader's fundamental beliefs and attitudes in ways that advance their achievement of "the good life." Like Wittgenstein, we can see Zhuangzi as carrying out a form of philosophical therapy, although unlike Wittgenstein, his main goal was not to untangle or dissolve philosophical issues but to instill in the readers a fresh set of perspectives that can counter our common psychological propensity toward anxiety. In the next section I discuss the notion of the "heavenly perspective," which Zhuangzi believed offers an important tool for sustaining an attitude of detachment and equanimity. (As we will see, this 
concept is unconnected to an appeal to God or deities.) We also explore what I call the virtue of spontaneity that Zhuangzi took as an important feature of human flourishing. Finally, I draw on Zhuangzi's views about the human good to identify some possible reasons against the use of genetic modification technologies.

Zhuangzi's Account of Flourishing: Heavenly Perspective and the Virtue of Spontaneity

The Zhuangzi, like the other classical Daoist text the Daodejing, is generally believed to be the work of more than one author, integrating ideas from multiple sources. Nevertheless, the text as a whole presents a substantive vision of what matters in life and the sorts of dispositions and attitudes we should cultivate to obtain a life that goes well for us. The goal of this section is to highlight the core elements of Zhuangzi's conception of well-being. ${ }^{5}$ Given the text's complexity and rich history, I am by no means offering a definitive interpretation. Nevertheless, I believe the discussion that follows captures key aspects of Zhuangzi's philosophical vision.

One of the central features of the positive vision of human flourishing advanced by Zhuangzi is freedom from the ordinary concerns that are constitutive of the struggle and anxiety permeating day-to-day life:

Sweating and laboring to the end of his days and never seeing his accomplishments, utterly exhausting himself and never knowing where to look (p.74) for rest-can you help pitying him? I'm not dead yet! he says, but what good is that? His body decays, his mind follows it-can you deny that this is a great sorrow? Man's life has always been a muddle like this. ${ }^{6}$

Zhuangzi offered a diagnosis of the ills that trouble us: moving without pause or rest from one task to another, we are so preoccupied with everyday affairs that our minds are incapable of finding genuine rest. This is a common psychological state that will resonate with most of us.

As Zhuangzi observed, our psychological disturbances are often the product of our inability to satisfy our numerous and ever-expanding set of desires. Of course, one way of resolving this predicament would be to find a way of satisfying all of our desires, but that is clearly a practically (perhaps even logically) impossible task. Rather, Zhuangzi suggested we need to cultivate a different perspective, one that builds and sustains a kind of equanimity that can shield us from the psychological pressures that afflict our minds. This perspective, which recent scholars, including Justin Tiwald and Philip J. Ivanhoe, have labeled the "heavenly perspective," offers a vantage point from which value distinctions and categories fade away, and every event is considered simply a part of the grand process of change: "Whether you point to a little stalk or a great pillar, a leper or the beautiful Xishi, things ribald and shady, or things 
grotesque and strange, the Way makes them all into one." 7 (I explain the Daoist notion of "the Way" in material that follows.)

To help understand this perspective, Justin Tiwald suggested reflecting on a "broad, panoramic, view of the universe over the fullness of time, and how human value distinctions, pretenses to knowledge, and absolutism must seem from that perspective." ${ }^{8}$ As I discuss further in this chapter, Zhuangzi was not advocating the heavenly perspective as the only proper way of seeing the world, but calling attention to its practical advantages. For example, the heavenly perspective loosens our confidence in the truth of our judgments concerning what is valuable or good, thereby allowing us to become more receptive to new ideas. $^{9}$

Hold on to all that you have received from Heaven, but do not think you have gotten anything. Be empty, that is all. The Perfect Man uses his mind like a mirror-going after nothing, welcoming nothing, responding but not storing. Therefore he can win out over things and not hurt himself. ${ }^{10}$

Being able to detach ourselves from our preconceived judgments and values, we place ourselves in a position of receptivity, cultivating an open-minded attitude. The heavenly perspective protects us from prematurely blocking off worthwhile considerations that may strike us as unappealing or even ludicrous. Another advantage is that by admitting the fallibility of our judgments, we are less anxious (p.75) about being in error and can detach ourselves from the kind of intellectual pride that is often the source of much personal frustration, as well as fruitless bickering.

Looking to help the readers cultivate the proper frame of mind to grasp the heavenly perspective, Zhuangzi concocted a combination of (at times outlandish) parables and rhetorical questions:

Now let me ask you some questions. If a man sleeps in a damp place, his back aches and he ends up half paralyzed, but is this true of a loach? If he lives in a tree, he is terrified and shakes with fright, but is this true of a monkey? Of these three creatures, then, which one knows the proper place to live? Men eat the flesh of grass-fed and grain-fed animals, deer eat grass, centipedes find snakes tasty, and hawks and falcons relish mice. Of these four, which knows how food ought to taste? Monkeys pair with monkeys, deer go out with deer, and fish play around with fish. Men claim that Maoqiang and Lady Li were beautiful; but if fish saw them, they would dive to the bottom of the stream; if birds saw them, they would fly away; and if deer saw them, they would break into a run. Of these four, which knows how to fix the standard of beauty for the world? The way I see it, the rules of benevolence and righteousness, and the paths of right and wrong 
all are hopelessly snarled and jumbled. How could I know anything about such discriminations? ${ }^{11}$

The primary function of these questions is to help the reader recognize that while our value judgments about beauty, welfare, or morality may seem indubitable to us (from both an individual and species-level point of view), they arise out of our own necessarily limited perspective. Indeed, from the perspective of every creature, what appears good or beautiful will seem obvious, and it is all too natural for us to move from what we find appealing to universal claims about what is absolutely good or beautiful, a significant mistake in Zhuangzi's eyes. Coming to recognize the degree to which our evaluative judgments vary depending on the particular perspective from which the judgment is made will make us less dogmatic in our stance and enable us to flexibly employ a wider range of considerations to resolve intellectual and practical challenges. Consider the following allegory:

When the monkey trainer was handing out acorns, he said, "You get three in the morning and four at night." This made all the monkeys furious. "Well, then," he said, "you get four in the morning and three at night." The monkeys were all delighted. There was no change in the reality behind the words, and yet the monkeys responded with joy and anger. Let them, if they want to. So the sage harmonizes with both right and wrong and rests in Heaven the Equalizer. This is called walking two roads. ${ }^{12}$

(p.76) We can imagine a less amenable monkey trainer stubbornly sticking to his plan to give three acorns in the morning and four at night, remarking with exasperation, "What difference does it make if they get four now and three later?" As it turns out, there is a significant difference from the monkeys' point of view, recognized by the astute trainer who simply adjusted to their preferences. Commenting on this passage, Thomas Merton described Zhuangzi's normative vision as "at home on two levels: that of the divine and invisible [D]ao that has no name, and that of ordinary, simple, everyday existence."13 As Merton went on to explain, despite initial appearances, Zhuangzi wasn't suggesting that we permanently stay within the heavenly perspective, detaching ourselves from every human desire and end. Rather, Zhuangzi was suggesting that we should seek to live well in the world as it is and to harmonize both the heavenly and human perspectives. ${ }^{14}$ On this picture, we continue to strive for the realization of certain goals, while recognizing that from the cosmic perspective our ends will appear insignificant. In a number of passages, Zhuangzi offered examples of Daoist exemplars that occupied simple, ordinary roles in society-butcher, woodcarver, ferry guide-that find a way of achieving the highest levels of perfection in their craft, while at the same time having their hearts set on following the Way, the Daoist path for achieving the best, most flourishing life. These so-called skill stories reveal Zhuangzi's paradoxical attitude that one must 
cultivate an attitude of detachment from, and skepticism toward, what we tend to value, at the same time manifesting excellence in one's ordinary work. ${ }^{15}$

An important element of Zhuangzi's conception of the flourishing life, as exemplified in the skillful practices of the Daoist masters, is living according to certain natural, spontaneous, or nonrational tendencies that allow one to move along the path of life with dexterity and tranquility, resulting in both interpersonal and intrapersonal harmony. Consider this description of the psychological state of the master butcher Cook Ding as he cuts up an ox: "And now-now I go at it by spirit and don't look with my eyes. Perception and understanding have come to a stop, and spirit moves where it wants. I go along with the natural makeup, strike in the big hollows, guide the knife through the big openings, and follow things as they are." 16 We can read the butcher's "flow"like activity (to borrow from Mihaly Csikszentmihalyi) metaphorically, referring to the way that our lives, when going exceedingly well, also seem to be carried along by a certain element of smoothness and effortlessness, where everything just seems to hang together properly, allowing us to live with balance and ease. I refer to the disposition that allows one to move forward in life with flow and tranquility through those nonrational spontaneous drives or inclinations identified by Zhuangzi as the virtue of spontaneity. ${ }^{17}$ The development and maintenance of this virtue is one of the core features of the Zhuangzian conception of human flourishing.

(p.77) As scholars have noted, Zhuangzi's choice of exemplars for articulating the best human lives were often those who are deemed least worthy of respect in early China: butchers, criminals, and those who are physically disfigured. Through these examples, Zhuangzi suggested that the range of lives that can go well is much broader than what most would think. As Philip Ivanhoe noted, "By calling into question established notions about what constitutes the good and the worthy, he illuminated forgotten corners of human dignity. . . All are part of the great dao and each has dignity and worth in itself." 18 This is in stark contrast to the prevailing attitudes about human worth in early China, which were closely bound with hierarchy and roles. In Zhuangzi's eyes the cultivation of the heavenly perspective allows one to see past culturally constructed norms and values and appreciate a sense of oneness that ties together all things, processes, and change. In a variety of passages we see Zhuangzi endorsing skepticism toward much of what we ordinarily value and accepting all events as simply the unfolding of the natural pattern set by heaven.

While cultivating a receptive, let it be attitude may be an effective mindset for daily life, one might worry that when confronting tragic events such an attitude may be out of place. In one well-known passage, when Zhuangzi's wife dies, his friend Huizi comes to visit only to find him singing in a cheerful mood. Huizi chastises him for his callousness, and Zhuangzi responds: 
When she first died, do you think I didn't grieve like anyone else? But I looked back to her beginning and the time before she was born. Not only the time before she was born, but the time before she had a body. Not only the time before she had a body, but the time before she had a spirit. In the midst of jumble of wonder and mystery, a change took place and she had a spirit. Another change and she had a body. Another change and she was born. Now there's been another change she's dead. It's just like progression of the four seasons: spring, summer, fall, winter. ${ }^{19}$

One might initially find Zhuangzi's comparison of the death of a loved one with a change in season as perverse. But as we see in the passage, even Zhuangzi underwent an initial period of grief. In line with his practical and therapeutic aims, we can interpret Zhuangzi as primarily seeking to offer a way to move past the experience of grief by taking on the heavenly perspective from which life and death appear as both necessary and inevitable events that are charged with "wonder and mystery." In Zhuangzi's eyes, life and death were mysteries that lie beyond the scope of our rational capacity. By framing such events as part of the ineffable processes of the natural world, Zhuangzi believed that his readers would find comfort that can ease the pain of loss and enable us to move forward with our lives. The Zhuangzian spirit is at home in a more intuition-driven, less rationally (p.78) focused way of life that finds consolation in the fact that many of life's most important experiences elude our rational grasp.

The conception of human flourishing that emerges from this discussion emphasizes the importance of cultivating an anxiety-free and open-minded attitude, with the ability to recognize that the importance we attach to our everyday affairs is, at least from a broader, cosmic perspective, insignificant. This perspective allows us to maintain equanimity in the face of challenges and to prevent ourselves from obsession with any particular goal, as well as suggesting that what most think of as meritorious, admirable, or ignoble are often the result of mere societal conventions and norms and do not match what is truly good from the perspective of the dao: the proper path that leads to the most flourishing life. Additionally, through the cultivation of the virtue of spontaneity, one leads a less rationally driven, more unencumbered life that moves with the grain of one's natural drives and inclinations.

But as noted, Zhuangzi was not claiming that we should aim to abandon our human perspective and extricate ourselves from all desires. As the stories of the Daoist exemplars reveal, those whose lives best exemplify the Daoist vision of well-being live fairly ordinary, simple lives that conform to basic cultural mores. But, in carrying out their ordinary tasks, they demonstrate excellence, and it is through their skillfulness that they discover a way to accord with the dao. The Daoist image of flourishing isn't that of a solitary hermit, but of someone living at peace in the world, according to one's natural impulses, harmonizing with both nature and other people. In Zhuangzi's view, much of what we think of as 
essential or important to our happiness-wealth, good looks, advanced technology - tends to distract us from a more enduring, deeper kind of joy that is achieved by a simplified life that is attuned to our more basic, natural promptings.

To summarize the discussion, let me identify two central elements of Zhuangzi's conception of flourishing:

\section{Heavenly Perspective. This perspective prevents narrow-minded} obsessions over trivial matters by allowing us to see events and people from a wider, more cosmic point of view. It allows us to face difficulties with equanimity and also to see that the values and norms we endorse are not timeless truths, but a product of culture and society, resulting in open-mindedness and receptivity toward finding value and worth in things and people that otherwise would have been neglected.

II. Virtue of Spontaneity. This virtue allows us to live according to the spontaneous inclinations rooted in our nature, which Zhuangzi believed will free us from our attachments to worldly goods and enable us to be at peace with ourselves and others. Because this form of life is best

achieved when (p.79) one is relatively free from worldly attachment-as exemplified by the Daoist sages like Cook Ding-it is marked by simplicity.

The Ethics of Gene Editing: Lessons from Zhuangzi

How might the use of genetic modification technologies affect the possibility of achieving the sort of life that Zhuangzi believed is best for us? Applying the values and ideas of an ancient Chinese thinker to a contemporary moral issue is bound to be messy, but it is possible to identify some considerations relevant to the ethics of gene editing. Given Zhuangzi's focus on the cultivation of the heavenly perspective and the virtue of spontaneity, I suggest that we at least have reason to think genetic modification would conflict with the account of human well-being proposed by Zhuangzi. The relevant question for our purposes is, How might the use of gene editing technology affect the sorts of dispositions and attitudes that Zhuangzi saw as essential for obtaining well-being?

One of the best-known objections to human genetic modification has been the way that such technologies strengthen what Michael Sandel called our "drive to mastery," thereby undercutting the "enlarged human sympathies that an openness to the unbidden can cultivate." ${ }^{20}$ Sandel's core idea was that these technologies ultimately discourage the cultivation of certain values and dispositions, especially the disposition to accept with humility and gratitude human beings as they are, which can foster a sense of solidarity with all people. In a similar spirit, Michael Hauskeller comments in this volume, "There is no best possible child (in the comparative sense). Instead there are many different ways of being good. And if we want to live a good life ourselves, if we want to 
flourish as human beings and want our children to flourish as well, we need to, perhaps more than anything else, recognize the multiple realizability of the good (p. 67 in Chapter 4)."21

There are significant elements of Sandel's and Hauskeller's normative outlook that I think Zhuangzi would find congenial, for example, accepting people as they are and recognizing the dignity and worth inherent in everyone. By becoming increasingly focused on finding ways to improve human nature and design human beings, we seem to go directly against the flexible, open-minded attitude that Zhuangzi thought was so crucial for flourishing. Take, for example, the attitude expressed by parents who hope to apply genetic technology to produce in their children traits such as a certain height, eye color, or level of intelligence. ${ }^{22}$ For Zhuangzi, the common assumption underlying this kind of use of genetic technology - that we have a sufficient understanding of which human traits are better than others-was dubious, particularly from the heavenly perspective. For Zhuangzi, much of our understanding concerning which human traits are more or less valuable is the result of cultural influences that far too often (p.80) deter us from really seeing the true worth of things-that is, their true worth according to the perspective of heaven. At the very least, we should be far less confident about the extent to which we possess such knowledge. Besides Zhuangzi's skepticism regarding our ability to correctly grasp values, there are other reasons why Zhuangzi would disapprove of the use of genetic modification technologies. I identify three next.

The first reason is that increasing the use of enhancement technologies would undermine the kinds of attitudes toward ourselves and the world that Zhuangzi thought were essential for living well. So, where Zhuangzi would take "wonder and mystery" to be the natural and intuitive responses to the birth of our children and the genetic qualities they possess, pervasive use of genetic technology could lead us to see birth as the product of human agency.

This is not an assessment shared by everyone. For example, Allen Buchanan has argued that even the rampant use of genetic enhancement technology would still leave many things outside human control. ${ }^{23}$ Moreover, as Buchanan also argued, not all human interventions in the processes of nature are bad: we cut out tumors, develop minds through education and learning, and grow genetically modified crops that yield greater quantities of healthier food. While these are legitimate points, they don't completely address the concern that by increasing our manipulation of the most profound and mysterious human events such as birth and death, we promote the disposition to seek greater control over nature -a disposition that lies in tension with the more detached attitude of the heavenly perspective. ${ }^{24}$ 
The second reason is that it isn't clear whether altering the human genome would, on the whole, be beneficial for us. On Zhuangzi's view, the requirements for living flourishing lives are much lower than people generally tend to think. A fairly simple life, as long as one cultivates the sorts of attitude we've identified, is sufficient for a high level of flourishing. There is empirical research that seems to support this point. In a study on life satisfaction levels by Ed Diener and Martin Seligman, the life satisfaction levels of the Forbes magazine's "richest Americans" were equal to the life satisfaction levels of the Pennsylvania Amish and the Inughuit (Inuit people in Northern Greenland), even though the lives of the Amish and Inughuit rank much lower in economic freedom. ${ }^{25}$

More important, Zhuangzi suggested that by increasing our options for the variety of goods that science generates, our lives are actually made worse-our minds are saturated with more expansive desires, which in turn cause greater frustration. Again, contemporary empirical research suggests that Zhuangzi was onto something. Studies of the Old Order Amish of Pennsylvania showed that their rate of nonmanic depression or "common cold depression" occurred at roughly between one-fifth and one-tenth of the depression rate among the citizens of Baltimore. ${ }^{26}$ This suggests that even though our lives have much greater (p.81) freedom in choosing from a range of economic goods compared to the Amish, in terms of subjective well-being, we may be doing a fair bit worse. Of course, to make the warranted judgment that city-dwelling Americans are overall doing worse than the Amish would require investigating the well-being of both populations as well as a variety of other factors. And while many of us may have fleeting thoughts about how wonderful and free it must feel to live like that - few of us would seriously consider joining the Amish community. One recent, notable exception is Matthew Secich, who was a sous chef at a world-renowned restaurant but decided after years of deep unhappiness to join the Amish community with his wife and family. Describing his current, radically simpler life, he commented:

This is far better. You can hear the clock tick. . . . I truly believe God has his destiny for all things. From once upon a time being a four-star chef, to playing with meat in the backwoods, that was all God's plan. I feel so blessed to be here. ${ }^{27}$

It's almost as if Secich was following a prescription suggested by Zhuangzi over two millennia ago: "Be content with this time and dwell in this order, and then neither sorrow nor joy can touch you. In ancient times this was called the 'freeing of the bound.' There are those who cannot free themselves because they are bound by things. But nothing can ever win against Heaven-that's the way it's always been."28 
The third reason Zhuangzi would take issue with the use of genetic technology draws on Zhuangzi's view that the heavenly perspective opens us up to see the dignity and worth that are present in lives that are too quickly dismissed by society. Because genetic enhancement, as scholars like Michael Sandel, Adrienne Asch, and Edmund Pellegrino have noted, may promote the sort of mindset that led to programs of eugenics in the early twentieth century-sharply demarcating what counts as desirable and undesirable traits in human beings; it could also decrease our capacity to appreciate just those kinds of lives that Zhuangzi saw as carrying the potential to flourish, including those who live with extremely unusual physical deformities. ${ }^{29}$ In her powerful reflection on disability in this volume, Rosemarie Garland-Thomson (Chapter 1) comments on the increasing drive toward removing all forms of genetic anomalies:

People like the four of us have long been the "bad news" of lying-in hospitals, delivery rooms, neonatal units, and prenatal imaging and testing - unexpected arrivals delivered by the Black Stork. In the swiftly developing world of genetic engineering, however, people like us are identifiable, legible in our distinctiveness and rarity, much earlier in the trajectory of medicalized human procreation than in the past. Detecting disability through selective testing is (p.82) carried out now at all developmental stages of human reproduction, from the gametic to the embryonic to the fetal to the neonatal. Germline interventions would seek to prevent people with rare diseases and congenital disabilities from coming into being. This pruning of human variation at the genetic level proceeds with little considerations of our perspectives as people who live out these genetic narratives. Enthusiasts about genetic engineering cite facts against us such as those described by the Global Burden of Disease Project, which calculates our supposed collective costs without accounting for our contributions. We are a vanishing tribe, those of us now detectable earlier and earlier in the process of human procreation. We are now often culled out before the traits that embryonic and fetal testing reveal are brought into being in a lived life. ${ }^{30}$

The march toward eradicating every genetic aberration has muted the voices of those who actually live with such conditions. Not only are we increasingly unable to appreciate the contributions that those with disabilities make to society, but also we now question whether such people should even exist. Consider this comment by the bioethicist Dena Davis:

In my own mind I can discern a subtle shift in the way in which I view people with certain anomalies. Twenty years ago, seeing a woman in the supermarket with a child who has Down syndrome, my immediate reactions were sympathy and a sense that that woman could be me. Now that testing for Down syndrome is virtually universal in the United States, 
when I see such a mother and child I am more likely to wonder why she didn't get tested. ${ }^{31}$

One aspect of the shift in Davis's attitude is that now, with advanced understanding of genetic screening, there shouldn't even exist people with "anomalies" at all. What is strikingly absent in the thoughts and attitudes of those like Davis is the perspective of those who actually carry those anomalies, which frequently tells a very different story about what their lives are like. As Garland-Thomson describes in Chapter 1 of this volume:

Living in a world not built for us and in a community where the majority of members understand themselves and are understood by others as being more fortunate, advantaged, better, more able, or healthier than we are has been an opportunity. From that place where we have lived our lives, many of us have developed a vibrant resourcefulness, interdependence, an alternative knowledge base, and a consciousness sometimes perceptible only in the recesses of our being, all of which have served us well. ${ }^{32}$

(p.83) Zhuangzi tells a story of a man named Ziqi who discovered a large tree that he deemed worthless: "He saw that the smaller limbs were gnarled and twisted, unfit for beams or rafters, and looking down, he saw that the trunk was pitted and rotten and could not be used for coffins. . . . It turns out to be a completely unusable tree."33 But in a flash of Daoist insight Ziqi realized that these anomalies had contributed to the tree's flourishing: "Aha! - it is this unusableness that the Holy Man Makes use of!"34

The crucial point Zhuangzi and Garland-Thomson highlighted is that without adequate reflection on the perspective of the disabled we will fail to appreciate how disabilities may serve as sources of prudential value. But the ability to recognize this fact is contingent on having a proper outlook, marked by the kind of open-mindedness and acceptance that Zhuangzi advocated throughout the text.

\section{Conclusion}

The point of this chapter was not to offer decisive reasons against the use of genetic modification technologies, but rather to draw attention to certain values and perspectives that Zhuangzi took as essential for human flourishing and that appear to be in tension with genome modification. Many contemporary readers -just like many thinkers in Zhuangzi's own time-will find Zhuangzi's conception of well-being, with its focus on detachment, heavenly perspective, and spontaneity, too narrow and implausible. There are two points to note in response. The first is that even if Zhuangzi's vision seems too radical for us, there are aspects of that vision, such as the abilities to shift perspectives, to detach oneself from particular ends, and to flow with the nonrational intuitive inclinations of our nature, that many will find appealing. The second point is that, given Zhuangzi's deep and enduring influence on the some of the best 
minds of the East, we have reason to believe he may be a resource to help us to examine some of our most basic-and therefore least analyzed-assumptions. Through deep and sympathetic engagement with profound thinkers of other cultures like Zhuangzi, we are less likely to become imprisoned by the particular values of our society and culture and more likely to extend our understanding of the possibilities for leading good human lives.

Notes:

(1.) I thank Josephine Johnston and Erik Parens for all their helpful comments. This work was supported by funding from the John Templeton Foundation.

(2.) Alberto Giubilini and Segar Sanyal, "The Ethics of Human Enhancement," Philosophy Compass 10, no. 4 (2015): 233-243.

(3.) Norman Daniels, "Normal Functioning and the Treatment-Enhancement Distinction," Cambridge Quarterly of Healthcare Ethics 9, no. 3 (2000): 309-322.

(4.) Briefly, somatic engineering alters somatic cells and would not result in changes that would be inherited by one's offspring. Germline engineering, which alters germ cells, would result in changes that would be passed down to one's offspring. The latter technology is generally considered as more ethically problematic.

(5.) I acknowledge that the text attributed to Zhuangzi is drawn from multiple sources and is the product of more than one thinker. But since there is a general consensus that Zhuangzi was a historical figure who espoused the basic ideas attributed to him, for convenience I refer to ideas of the text as "Zhuangzi's views."

(6.) All translations of the Zhuangzi, unless noted otherwise, are from Burton Watson, trans., The Complete Works of Zhuangzi (New York: Columbia University Press, 1968), 33.

(7.) Watson, Zhuangzi, 11.

(8.) Justin Tiwald, "Well-Being and Daoism," in The Routledge Handbook of the Philosophy of Well-Being, ed. Guy Fletcher (London: Routledge, 2016), 62. I am greatly indebted to Tiwald's essay for many of the ideas explored in this chapter.

(9.) Tiwald, "Well-Being."

(10.) Watson, Zhuangzi, 59.

(11.) Watson, Zhuangzi, 15. 
(12.) Watson, Zhuangzi, 11.

(13.) Thomas Merton, The Way of Chuang Tzu, 2nd ed. (New York: New Direction Publishing, 2010), 32.

(14.) For Western scholars, it may be helpful to contrast the heavenly and human perspectives with what Thomas Nagel called the "subjective" and "objective" points of view. See Thomas Nagel, The View from Nowhere (Oxford: Oxford University Press, 1986). While there are certainly notable differences, one common feature is that as we move back to a more cosmic point of view, what matters to us will gradually appear as less significant. But while, as I understand it, Nagel's inquiry was more conceptually and theoretically oriented, Zhuangzi employed the heavenly perspective for practical ends that he took to offer significant prudential benefits.

(15.) For philosophical discussions of the skillful stories and their role in Zhuangzi's thought, see Essays on Skepticism, Relativism, and Ethics in the Zhuangzi, ed. Paul Kjellberg and Philip J. Ivanhoe (Albany: SUNY Press, 1996).

(16.) Watson, Zhuangzi, 19.

(17.) The concept of "spontaneity" is complicated, and more discussion is needed than I can offer here. Here I mean to employ it within the context of the Daoist worldview, which suggests that there are certain "natural" inclinations, emotions, and attitudes that are in tune with the Dao or Nature. For his account of "flow," see Mihaly Csikszentmihalyi, Flow: The Psychology of Optimal Experience (New York: Harper and Row, 1990).

(18.) Philip J. Ivanhoe, "Was Zhuangzi a Relativist?” in Kjellberg and Ivanhoe, Essays on Skepticism, 206-207.

(19.) Watson, Zhuangzi, 140-141.

(20.) Michael Sandel, The Case Against Perfection: Ethics in the Age of Genetic Engineering (Cambridge, MA: Harvard University Press, 2007), 47.

(21.) See Michael Hauskeller, "Editing the Best of All Possible Worlds," Chapter 4 , this volume.

(22.) There are important empirical questions about what is genuinely within the realm of practical possibility with regard to genetic technology, and we should not exaggerate what can realistically be achieved by it.

(23.) Allen Buchanan, "Enhancement and the Ethics of Development," Kennedy Institute of Ethics Journal 18, no. 1 (2008): 1-34. 
(24.) But whether the changes of nature through human enhancement are of overall benefit to human beings would require us to ask whether the benefits conferred by such enhancement outweigh the loss incurred by it. This, however, is at least in part an empirical issue since we would need to know what the real psychological consequences of pursuing such technology would be.

(25.) Ed Diener and Martin E. P. Seligman, "Beyond Money: Toward an Economy of Well-Being," Psychological Science in the Public Interest 5, no. 1 (2004): 1-31.

(26.) Martin Seligman, "Why Is There So Much Depression Today? The Waxing of the Individual and the Waning of the Commons," in Contemporary Psychological Approaches to Depression Theory, Research, and Treatment, ed. Rick E. Ingram (New York: Plenum Press, 1990), 1-9.

(27.) Abigail Curtis, "Former Big-City Chef Turns Amish, Makes Charcuterie in Rural Maine," Bangor Daily News, January 13, 2016, http:// bangordailynews.com/2016/01/13/homestead/former-big-city-chef-turns-amishmakes-charcuterie-in-rural-maine/

(28.) Watson, Zhuangzi, 48.

(29.) Michael Sandel, The Case Against Perfection, 63-83; Leon Kass, "Defending Human Dignity," in Human Dignity and Bioethics: Essays Commissioned by the President's Council on Bioethics, ed. Pellegrino Edmund D., Adam Schulman, and Thomas W. Merrill (Washington, DC: The President's Council on Bioethics, 2008), 301; Edmund Pellegrino, "The Lived Experience of Human Dignity," in Kass, Human Dignity and Bioethics, 515.

(30.) Rosemarie Garland-Thomson, "Welcoming the Unexpected," Chapter 1, this volume, XX-XX.

(31.) Dena S. Davis, Genetic Dilemmas: Reproductive Technology, Parental Choices, and Children's Futures, 2nd ed. (Oxford: Oxford University Press, 2010), 19.

(32.) Garland-Thomson, "Welcoming the Unexpected," XX.

(33.) Watson, Zhuangzi, 31.

(34.) Watson, Zhuangzi, 31.

\section{Access brought to you by:}

